\title{
Detection of Land Damage for Biomass Production with Thematic Overlays based Geographic Information Systems
}

\author{
Nunung Sondari ${ }^{1 *}$, Rohana Abdullah ${ }^{1}$, Rineu Agustine ${ }^{2}$, Candra P. Nurlukman ${ }^{1}$, Hudaya \\ Mulyana $^{1}$ and Elly Roosma Ria ${ }^{1}$
}

Date Received: $18^{\text {th }}$ December 2019 / Date Accepted: $30^{\text {th }}$ January 2020

\begin{abstract}
Purpose : Nationally, not all regions in Indonesia have detected land damage for biomass production. Whereas the determination of land damage needs to be done as an effort of its control. The aim of this study is to compile a map of the status of soil and land damage for Biomass production.
\end{abstract}

Research Method: This research was conducted with a scoring calculation method with a thematc map overlay using a Geographic Information System.

Findings : The results showed in 12 study areas, where they had an area of 58.509,31 ha of Effective Work Area, with three categories of potential land damage, namely $56.96 \%$ moderate damage, $43 \%$ minor damage, and $0.004 \%$ very mild damage.

Limitations : It would be better taking a sampling point even if the soil type is the same.

Value : As a form of the Minimum Service Standards for the Environment Sector, which is status information service based on the standard criteria for national land damage.

Keywords: land damage, biomass production, map overlay

\section{INTRODUCTION}

The land has a function as a matrix where the roots of anchor plants and water are stored. Therefore, the process of restoration of soil ecological functions becomes important especially in increasing the production of biomass which is very important for human welfare. In Ghana, mapping information on land damage for biomass production has been applied and is consistent in developing environmentally friendly agriculture in each district. One of the biggest challenges is reversing land management properly and unsustainable degradation. Technology and innovative principles must be applied to characterize land.

Determination of land damage status for biomass production needs to be done as an effort to control land damage. Land damage for biomass production can be caused by its natural nature, it can also be caused by human activities that cause the land to be disturbed / damaged until it is no longer able to function as a medium for normal biomass production. According to Mohamed and Abdel Rahman strengthened by opinions of Kjeld Rasmussen, Cheikh Mbow, Yunjia Wang, and Rasmus Fensholt the incorporation of soil survey information can be integrated in a geographic information system (GIS) to assess the suitability of plants for various soil and biophysical conditions. This study was carried out in effective work areas, namely, agriculture, plantation, and plantation areas whereas other areas (protected areas, other cultivation areas such as fishing ponds, settlements) are not included as effective work areas.

\footnotetext{
${ }^{*}$ Faculty of Agriculture, Universitas Winaya Mukti nunungsondari@unwim.ac.id

2 Department of Environment of Subang Regency, West Java Province, Indonesia.
}

D ORCID https://orcid.org/0000-0001-9064-8668 
Subang Regency with a total area of $205.176,95$ hectares or around $6.34 \%$ of the area of West Java Province is faced with the problem of potential damage to land resources. The encroachment of protected forest areas and land uses that are not suitable for their allotment and carrying capacity are actions that may be taken by the community due to increased population growth accompanied by an increase in their living needs including food, clothing, and housing. The location has been chosen for review and then the condition of the land damage status is determined based on the measurement results (the standard criteria for soil damage for biomass production in 2018). The activity of compiling Information and Monitoring the Status of Damage to Biomass Production Land in Subang Regency 2018 is in the form of documents resulting from monitoring and inventory of potential damage to biomass production land. According to Gibbs and Salmon (2018) land degradation is often suggested as a solution to the problem of land scarcity and as an ideal way to do it in meeting the increasing global demand for agricultural products.

\section{MATERIAL AND METHOD}

The study area is part of the Central and Southern Subang District covering twelve districts: Ciater District (6.572,18 ha), Cikaum District (7.545,44 ha), Cisalak District $(9.922,46$ ha), Dawuan District (9.335,03 ha), Jalancagak District (5,323.54 ha), Kasomalang District (5.029,10 ha), Pabuaran District (7.408,41 ha), Pagaden District (4.890,30 ha), West Pagaden District $(5,064.82$ ha), Purwadadi District (7.585,83 ha), Sagalaherang District (5.159,37 ha), and Serangpanjang District (7.202,68 ha).

The equipment used in this study includes field and laboratory equipments; steel ring sampler for intact land sampling, physical soil characteristics, composite soil sampling disturbed by drill and hoe, for analysis of soil chemical and biological properties. Garmin 62S handheld GPS, measuring instruments, documentation, abney level, stationery, striker labels, and plastic bags and ArcGIS 10.6 for making work maps and results maps.

Laboratory equipment is used to measure and establish land characteristics after field ground check. Some maps: land use maps, land maps, slope maps, (Fine Earth Map, Bakosurtanal / BIG). The term topographical features can also be found in Presidential Regulation (Perpres) Number 112 of 2006 concerning Standardization of Topographical Names. Term the second for topographic names is geographical names. This name still remains used by some people, including academics. The third term for name topographical is a toponym. This word comes from the Greek, meaning topos place and onyma meaning names (Rais, et al., 2008) then overlaid and scored to produce a map of potential land damage. The initial stage of preparing the initial Condition Map is to capture the effective work area through overlays with the Regional Spatial Planning Map. The weighting score for potential land damage is obtained by multiplying the rating value, namely, the potential value of each element of the thematic map to the occurrence of the land damage with the weight value of each thematic map (Technical Guidelines of the Ministry of Environment, 2009). The rating value is set to the range from 1-5. Land cover maps and land maps are given a weight value of 2 (two), slope and rainfall maps are given a weight of 3 (three). The higher the weighting scoring value, the higher the potential for the area to be experienced land damage. Scoring potential for land damage can be seen in Table 01.

Spatial analysis is done by overlaying some of the spatial data parameters determining land damage. Preliminary Condition Map in principle presents information on the alleged potential damage to the land in Figure 01.

This map will be used as a work map and aims to facilitate and direct verification in the field, especially in determining the priority of locations to be surveyed for measurements to be processed. For this purpose, it is necessary to know land damage, namely, land type, slope, annual rainfall and land use. 
Table 01: $\quad$ Scoring Potential Damage based on Thematic Map

\begin{tabular}{lcccc}
\hline \multicolumn{1}{c}{ Soil } & $\begin{array}{c}\text { Potential Land } \\
\text { Damage }\end{array}$ & Symbol & Rating & $\begin{array}{c}\text { weighting score } \\
\text { (rating x weight) }\end{array}$ \\
\hline Vertisol. soil with an aquatic moisture regime & Very lightly & T1 & 1 & 2 \\
Vertisol. soil with an aquatic moisture regime & Lightly & T2 & 2 & 4 \\
Oxisol & Moderate & T3 & 3 & 6 \\
Alfisol. Mollisol. Ultisol & High & T4 & 4 & 8 \\
Inceptisols. Entisol. Histosols & Very High & T5 & 5 & 10 \\
Spodosol. Andisol & & & & \\
\hline Slope (\%) & Very lightly & 1.1 & 1 & 3 \\
\hline $1-8$ & Lightly & 1.2 & 2 & 6 \\
$9-15$ & Moderate & 1.3 & 3 & 9 \\
$16-25$ & High & 1.4 & 4 & 12 \\
$26-40$ & Very High & 1.5 & 5 & 15 \\
$>40$ & & & & \\
\hline Rain Fall (mm/th) & Very lihgtly & H1 & 1 & 3 \\
\hline$<1000$ & Lightly & H2 & 2 & 6 \\
$1000-2000$ & Moderate & H3 & 3 & 9 \\
$2000-3000$ & High & H4 & 4 & 12 \\
$3000-4000$ & Very High & H5 & 5 & 15 \\
$>4000$ & & & & \\
\hline Land Use & Very lightly & T1 & 1 & 2 \\
\hline Nature forest; Rice field Pure Imperata Reeds & Lightly & T2 & 2 & 4 \\
Plantation Shurbs & Moderate & T3 & 3 & 6 \\
Production Forest & High & T4 & 4 & 8 \\
Annual Plant & Very High & T5 & 5 & 10 \\
Deforestation & & & & \\
\hline
\end{tabular}

Tabel 02: $\quad$ Criteria for classifying potential soil damage based on scores

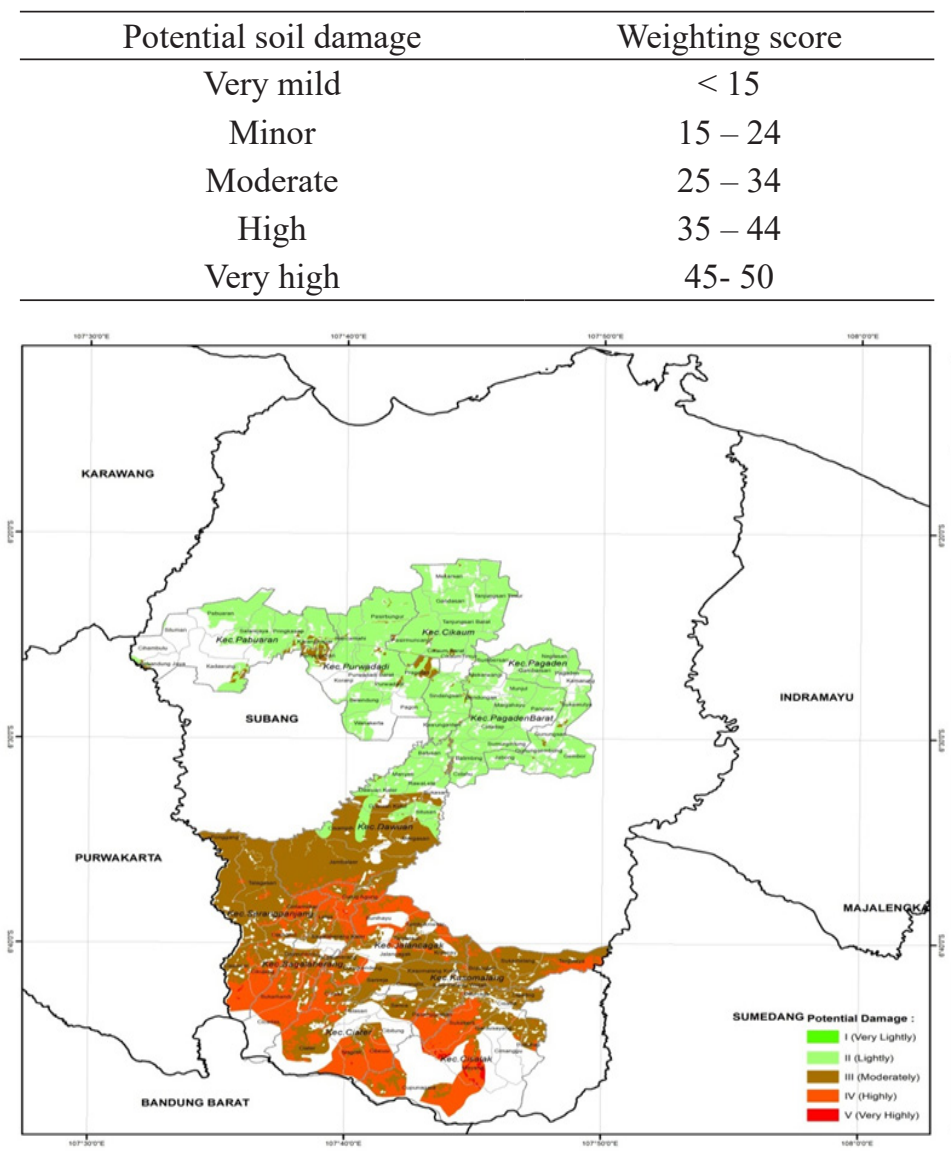

Figure 01: Potential land damage map 
Potential land damage is estimated by grouping the weighting score accumulation, which is the product of the score with the weight of each thematic map. This potential assessment is carried out on polygons generated through the overlay process. The value of the accumulated score ranges from 10 - 50. The maximum value occurs if all the attribute values from each used thematic map have a very high potential for soil damage and are listed in Table 02.

The field survey aims to improve the map of the results of the preparation of potential land damage by taking a coordinate sample (Table.03) with a sampling intensity of $2.5 \%$ of the priority area. Then the input map is reviewed and overlaid again.

\section{Laboratory Analysis}

Soil parameters for dry land as regulated in Minister of Environment Regulation No. 7 of 2006 concerning Procedures for measuring the criteria of Damage to Land for Biomass Production include: Solum Thickness, Surface Unity, Fraction Composition, Bulk Density, Total Porosity, Water Graduation Degree, $\mathrm{pH}$. Electrical Conductivity, Redox Value, Amount of Soil Microbes. All parameters mentioned are shown in Figure 02.

Table 03: Coordinates of Sample Points in the Study Area

\begin{tabular}{lcc}
\hline \multicolumn{1}{c}{ Land used } & $\mathrm{X}$ & $\mathrm{Y}$ \\
\hline Plantation & 792685.939 & 9253309.122 \\
Dry land & 804401.515 & 9255758.753 \\
Plantation & 803431.873 & 9257921.448 \\
Rain-Field Rice & 792023.918 & 9260122.121 \\
plantation & 788107.036 & 9260476.475 \\
Irrigated Field Rice & 799996.545 & 9263130.205 \\
Rain-Field Rice & 797454.856 & 9273555.976 \\
Plantation & 802668.997 & 9278605.280 \\
Irrigated Field Rice & 810779.474 & 9282201.524 \\
Dry land & 797166.676 & 9288649.672 \\
Dry land & 792302.548 & 9289856.040 \\
Irrigated Field Rice & 806173.080 & 9291882.811 \\
\hline
\end{tabular}

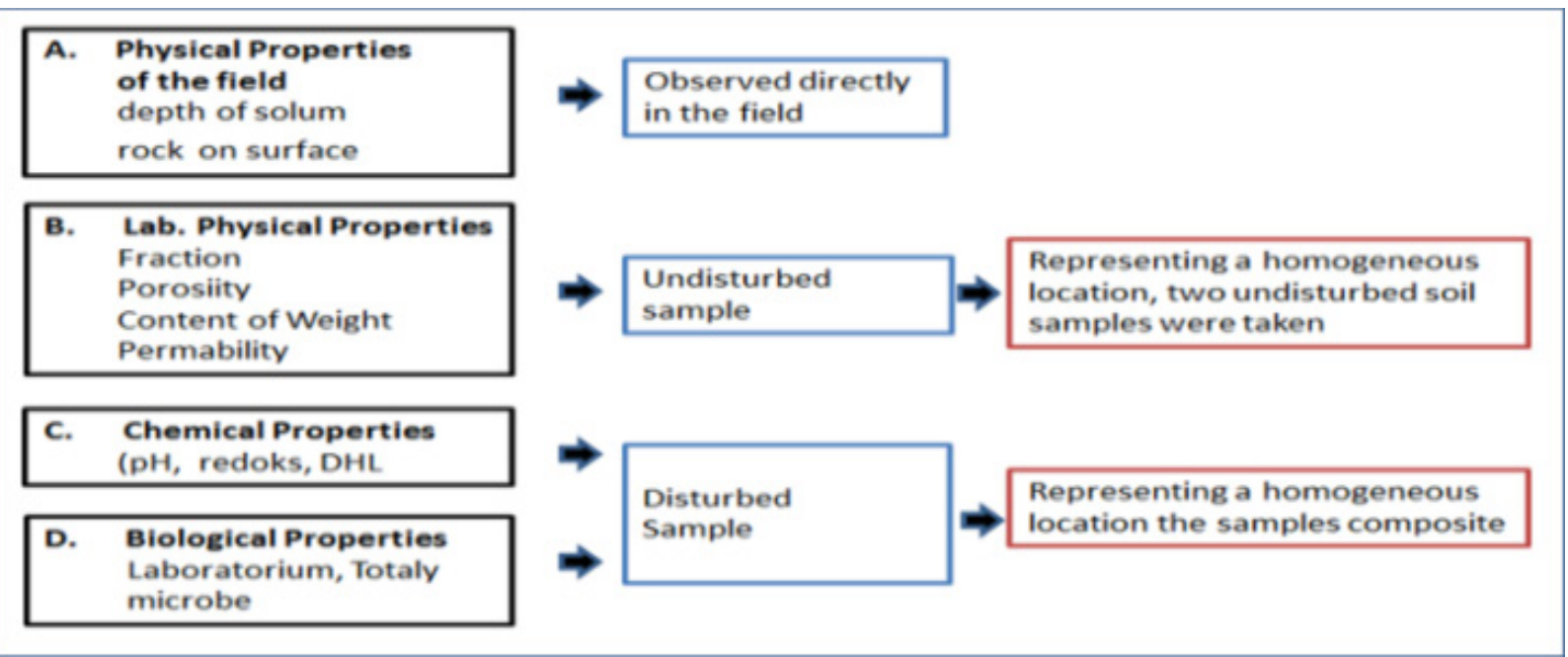

Figure 02: $\quad$ Scheme of Analysis of Dry Soil Quality Samples 


\section{Table 04: $\quad$ Standard Criteria for Soil Damage}

\begin{tabular}{|c|c|c|c|c|}
\hline No & Parameter & Critical threshold & Measurment Metode & Tools/Equipment \\
\hline 1 & Solum Thicknes & $<20 \mathrm{~cm}$ & Direct measurment & \\
\hline 2 & Surface rocks & $>40 \%$ & $\begin{array}{l}\text { Direct measurement of } \\
\text { stone and soil balance in a } \\
\text { unit area }\end{array}$ & $\begin{array}{l}\text { Tape measure } \\
\text { Tape measure: Counter (line } \\
\text { orto-tal) }\end{array}$ \\
\hline 3 & $\begin{array}{l}\text { Fraction } \\
\text { composition }\end{array}$ & $\begin{array}{l}<18 \% \text { claycoloid } \\
>80 \text { Quartz sand } \\
\text { Coarse sand }\end{array}$ & Color of sand. Gravimetric & $\begin{array}{l}\text { Graduated cylinder/beaker } \\
\text { glass/Weigher/steel yard }\end{array}$ \\
\hline 4 & Bulk Density & $>1.4 \mathrm{~g} / \mathrm{cm} 3$ & $\begin{array}{l}\text { Gravimetry In units of } \\
\text { volume }\end{array}$ & $\begin{array}{l}\text { Candles. measuring tubes; } \\
\text { ring sampler. analytical } \\
\text { balance }\end{array}$ \\
\hline 5 & Totaly porosity & $<30 \% ;>70 \%$ & $\begin{array}{l}\text { Calculation of content } \\
\text { weight }(\mathrm{BI}) \text { and specific } \\
\text { gravity }(\mathrm{BJ})\end{array}$ & $\begin{array}{l}\text { Picnometer; double ring per- } \\
\text { meameter }\end{array}$ \\
\hline 6 & Permeability & $\begin{array}{l}<0.7 \mathrm{~cm} / \mathrm{jam}> \\
8 \mathrm{~cm} / \mathrm{jam}\end{array}$ & Permeability & $\begin{array}{l}\text { Ring sampler; dou-ble ring } \\
\text { Permeameter }\end{array}$ \\
\hline 7 & $\mathrm{pH}\left(\mathrm{H}_{2} \mathrm{O}\right) 1: 2.5$ & $<4.5:>8.5$ & Potentiometrics & $\begin{array}{l}\mathrm{pH} \text { meter; } \mathrm{pH} \text { stick } 0.5 \text { scale } \\
\text { unit }\end{array}$ \\
\hline 8 & $\begin{array}{l}\text { Electrical } \\
\text { conductivity }\end{array}$ & $>4.0 \mathrm{~ms} / \mathrm{cm}$ & Electric resist & EC Meter \\
\hline 9 & Redoks & $<200 \mathrm{mV}$ & Electrical voltage & pH meter: platinun electrode \\
\hline 10 & Total of microbe & $<102 \mathrm{cfu} / \mathrm{g}$ tanah & Plating technique & Petri dish: Colony Counter \\
\hline
\end{tabular}

Steps to determine the level of land and land damage:

1. Calculate the relative frequency $(\%)$ of each land damage parameter.

2. Rating for each parameter based on relative frequency with a range value of $0-4$;

3. Add up the scores for each damage parameter of the soil.

4. Status of land damage is determined by the number of scores in point 3 .

\section{RESULT AND DISCUSSION}

Field verification is an activity to prove the indication of land damage that has been compiled from the results of field observations. Verification is carried out at the point of sampling and laboratory testing entered into the database from the total score given by categorizing the level of land damage listed in Table 05. The next step is to prepare a map of land damage obtained from a combination of potential damage maps and results of soil analysis in the laboratory. Based on the status of the damage this is divided into five categories namely, undamaged $(\mathrm{N})$, lightly damaged (RI), moderately damaged (R.II), heavily damaged (R.III) and very heavily damaged (R.IV). (1) Ciater. (2) Cikaum (3) Cisalak (4) Dawuan (5) Jalancagak (6) Kasomalang (7) Pabuaran (8) Pagaden (9) Pagaden Barat. (10) Purwadadi (11) Sagalaherang (12) Serangpanjang.

The database can be displayed in Table 05 and matched with the standard criteria for soil or land damage. The results of determining the damage status of the land are used to revise the map of potential land damage resulting from an overlay of spatial parameters (slope maps. rainfall maps. land cover maps. and maps of the distribution of soil types). In Figure 03 of the land damage status map very lightly marked in green is not visible. 
Table 05: Analysis of land damage database in the study area

\begin{tabular}{|c|c|c|c|c|c|c|c|c|c|c|c|c|}
\hline Parameter analysis & I & II & III & IV & $\mathrm{V}$ & VI & VII & VIII & IX & $\mathrm{X}$ & XI & XII \\
\hline District & 1 & 2 & 3 & 4 & 5 & 6 & 7 & 8 & 9 & 10 & 11 & 12 \\
\hline Potential Damage & $\mathrm{H}$ & $\mathrm{H}$ & $\mathrm{H}$ & $\mathrm{H}$ & $\mathrm{H}$ & $\mathrm{H}$ & M & M & M & M & M & M \\
\hline Symbol & PR-IV & PR-IV & PR-IV & PR-IV & PR-IV & PR-III & PR-III & PR-III & PR-III & PR-III & PR-III & PR-II \\
\hline Solum Thickness & $\mathrm{N}$ & $\mathrm{N}$ & $\mathrm{N}$ & $\mathrm{N}$ & $\mathrm{N}$ & $\mathrm{N}$ & $\mathrm{N}$ & $\mathrm{N}$ & $\mathrm{N}$ & $\mathrm{N}$ & $\mathrm{N}$ & $\mathrm{N}$ \\
\hline Spesific Gravity g/cm3 & $\mathrm{N}$ & $\mathrm{N}$ & $\mathrm{N}$ & $\mathrm{N}$ & $\mathrm{N}$ & $\mathrm{N}$ & $\mathrm{N}$ & $\mathrm{N}$ & $\mathrm{N}$ & $\mathrm{N}$ & $\mathrm{N}$ & R-II \\
\hline Total Porosity (\%) & R-II & $\mathrm{N}$ & $\mathrm{N}$ & $\mathrm{N}$ & $\mathrm{N}$ & $\mathrm{N}$ & $\mathrm{N}$ & $\mathrm{N}$ & $\mathrm{N}$ & $\mathrm{N}$ & $\mathrm{N}$ & R-III \\
\hline $\begin{array}{l}\text { Permeability } \\
\text { (cm/hour) }\end{array}$ & R-III & $\mathrm{N}$ & $\mathrm{N}$ & $\mathrm{N}$ & $\mathrm{N}$ & R-III & R-III & $\mathrm{N}$ & $\mathrm{N}$ & R-II & R-III & R-III \\
\hline Surface rock & $\mathrm{N}$ & $\mathrm{N}$ & $\mathrm{N}$ & $\mathrm{N}$ & $\mathrm{N}$ & $\mathrm{N}$ & $\mathrm{N}$ & $\mathrm{N}$ & $\mathrm{N}$ & $\mathrm{N}$ & $\mathrm{N}$ & $\mathrm{N}$ \\
\hline Fraction & $\mathrm{N}$ & $\mathrm{N}$ & $\mathrm{N}$ & $\mathrm{N}$ & R-II & $\mathrm{N}$ & $\mathrm{N}$ & R-II & R-II & $\mathrm{N}$ & R-III & R-III \\
\hline pH H2O & $\mathrm{N}$ & R-III & R-II & R-II & R-III & R-III & R-III & R-II & R-III & $\mathrm{N}$ & R-II & R-III \\
\hline Electrical coductivity & $\mathrm{N}$ & $\mathrm{N}$ & $\mathrm{N}$ & $\mathrm{N}$ & $\mathrm{N}$ & $\mathrm{N}$ & $\mathrm{N}$ & $\mathrm{N}$ & $\mathrm{N}$ & $\mathrm{N}$ & R-I & R-II \\
\hline Redoks (mV) & $\mathrm{N}$ & & $\mathrm{N}$ & $\mathrm{N}$ & $\mathrm{N}$ & R-III & $\mathrm{N}$ & $\mathrm{N}$ & R-III & $\mathrm{N}$ & $\mathrm{N}$ & R-III \\
\hline $\begin{array}{l}\text { Amount of Microbes } \\
\text { (cfu/g soils) }\end{array}$ & $\mathrm{N}$ & $\mathrm{N}$ & $\mathrm{N}$ & $\mathrm{N}$ & $\mathrm{N}$ & $\mathrm{N}$ & $\mathrm{N}$ & $\mathrm{N}$ & $\mathrm{N}$ & $\mathrm{N}$ & R-II & R-III \\
\hline Pyrit/FeS2 & $\mathrm{N}$ & $\mathrm{N}$ & $\mathrm{N}$ & $\mathrm{N}$ & $\mathrm{N}$ & $\mathrm{N}$ & $\mathrm{N}$ & $\mathrm{N}$ & R-II & $\mathrm{N}$ & $\mathrm{N}$ & R-III \\
\hline Land Damage Status & R-III & R-III & R-II & R-II & R-III & R-III & R-II & R-II & R-III & R-II & R-III & R-III \\
\hline
\end{tabular}

H: High ; M: Moderate

Sources: Data is processed based on the results of laboratory soil research centers. 2018

Some areas that were initially, potentially of high damage experienced a decrease in damage status to moderate and mildly damaged after soil analysis in the laboratory. Based on Table 05 below from an effective working area of $58.509,31$ ha. soil / land damage at a moderate level reached 33.328,16 ha. dominated by Serangpanjang District reaching an area of
$6.412,40$ ha. which is a mixed dryland garden united with melastoma bush (Melastoma malabatricum), Andisol soil type and the land has not been utilized optimally. The slope is of $16 \%-25 \%$. So, it is necessary to make a mixed garden design based on vegetative conservation methods.

Table 06: $\quad$ Status of Soil Damage

\begin{tabular}{clcccc}
\hline \multirow{2}{*}{ No } & \multirow{2}{*}{ District } & \multicolumn{3}{c}{ Level of Soil damaged } & \multirow{2}{*}{ Area (ha) } \\
\cline { 2 - 4 } & & I (Very mild) & II (minor/lightly) & III (Moderately) & \\
\hline 1 & Ciater & & $4.310,68$ & $4.310,68$ \\
2 & Cikaum & $6.128,37$ & 139.74 & $6.268,10$ \\
3 & Cisalak & & $4.695,02$ & $4.695,02$ \\
4 & Dawuan & \multirow{2}{*}{4.59} & $5.321,94$ & $3.056,14$ & $8.382,67$ \\
5 & Jalancagak & & $3.932,47$ & $3.932,47$ \\
6 & Kasomalang & & 2.24 & $4.477,01$ & $4.479,25$ \\
7 & Pabuaran & $3.263,58$ & 138.06 & $3.401,63$ \\
8 & Pagaden & $3.504,86$ & 100.21 & $3.605,06$ \\
9 & PagadenBarat & $3.889,89$ & 20.61 & $3.910,50$ \\
10 & Purwadadi & $5.065,69$ & 214.78 & $5.280,47$ \\
11 & Sagalaherang & & & $3.831,04$ & $3.831,04$ \\
12 & Serangpanjang & & & $6.412,40$ & $6.412,40$ \\
& Grand Total & & & $33.328,16$ & $58.509,31$ \\
\hline
\end{tabular}




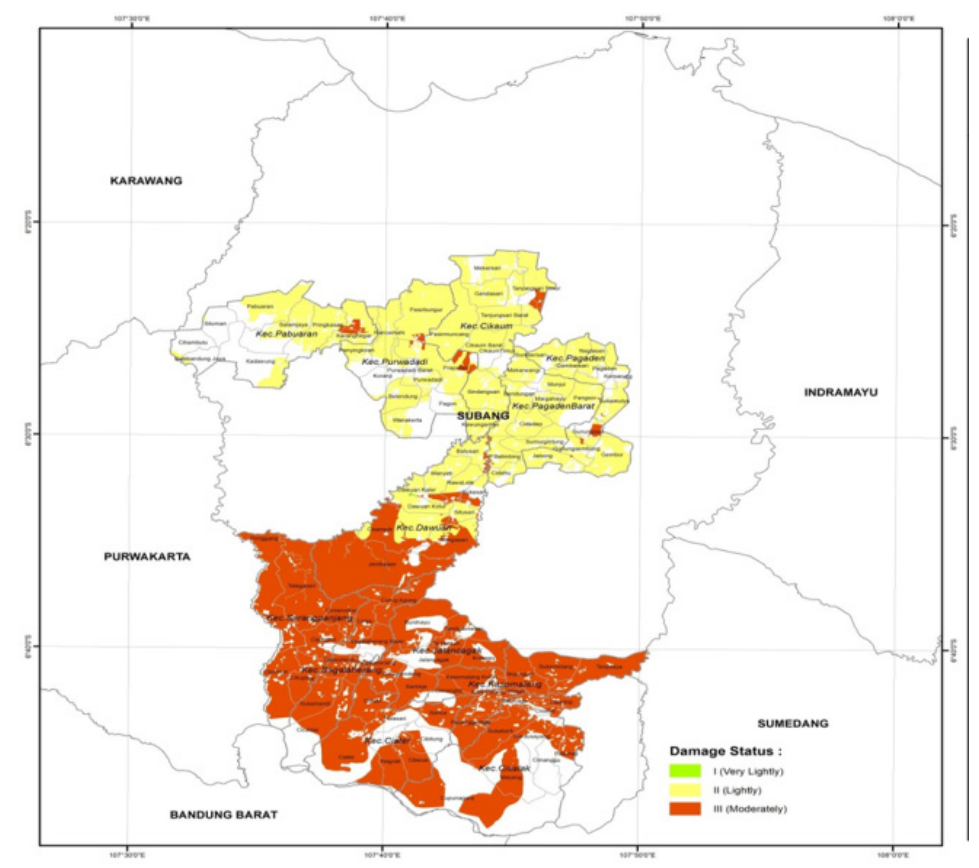

\section{Figure 03: $\quad$ Land Damage Status Map}

In Kasomalang District moderate damage was 4.695,02 ha. Land cover of mixed garden vegetation and soil / land damage can be seen from the degree of water release / permeability very quickly reaching $15.42 \mathrm{~cm} /$ hour.

Soil damage of $\mathrm{pH} 3.8$ as a leachate category of a number of bases in the soil layer and support of slope between $16 \%-25 \%$ of Latosol soil types. If the land is to be used for better mixed garden design it should be adjusted to regreening patterns utilizing agricultural lime and organic fertilizer (applying conservation with appropriate vegetative methods). Efforts to repair land damage can be done with conservation techniques both physically, chemically and biologically. Improvements can be done in several ways including the use of terraces on sloped lands, improved drainage on stagnant soils, lime application, ameliorant to improve soil $\mathrm{pH}$ and the provision of organic fertilizer to maintain soil conditions so as not to easily lose nutrients. According to Nunung Sondari (2017) one form of "safety net for leaching nutrients" is important. actions such as immersing forage materials are added to add organic material to the soil.

\section{CONCLUSIONS}

The determination results for the status of soil/ land damage indicate that their status in the twelve Districts in the effective work area is $56.96 \%$ for the medium damage category, $43 \%$ for the mild damage category, and $0.004 \%$ for the very light category.

\section{Data Availability Statement}

All data generated or analysed during this study are included in this published article and are available with supplementary information files.

\section{ACKNOWLEDGMENT}

Authors would like to thank to Universitas Winaya Mukti for providing full support of research collaboration. Authors thank Subang Regency's Office of the Environment for funding supports.

\section{REFERENCES}

Agency for geospasial Information. 2009-2013. Map of Rupa Bumi. RBI 2019-2023 Subang map centra. $1: 250.000$ scale. 2019 redigitzing. 
Albert Nii-Moe Allotey.2018. Geospatial Technique Approach to Land Degradation Assessments in Ghana. Geospatial Technique Approach to Land Degradation Assessments in Ghana: The Case of the Ejura Sekyedumase District CSIR - Council for Scientific and Industrial Research - Ghana. 9 PUBLICATIONS 28 CITATIONS. The Case of the Ejura Sekyedumase District. See discussions. stats. and author profiles for this publication at: https://www.researchgate. net/publication/333677894. DOI: https://doi.org/10.5897/jahr12.023

Ali Mahrus. Hariyadi Bambang Wicaksono. Nurlina. Hasyim Cholil. and Mudjanarko Sri Wiwoho5. Agriculture. 2017. Mapping of Biomass Production of Land Damage Assessment to Reduce Environmental Changes In East Java Probolinggo. MATEC Web of Conferences 138. 09004 (2017) DOI: https://doi.org/10.1051/matecconf/201713809004

H.K. Gibbs. J.M. Salmon. 2018. Mapping the world's degraded lands'. Applied Geography. journal homepage: www.elsevier.com/locate/apgeog Feng Tian. Martin Brandt . Yi Y. Liu. Aleixandre Verger . Torbern Tagesson . Abdoul A. Diouf.

Hardjowigeno. S. 2015. Ilmu tanah. Edisi revisi. Akademika Pressindo. Jakarta.

Kementerian Lingkungan Hidup Republik Indonesia. 2010. Himpunan Peraturan Perundangundangan di Bidang Perlindungan dan Pengelolaan Lingkungan Hidup (Buku Jilid 2). Halaman 2065. Lampiran: Peraturan Menteri Negara Lingkungan Hidup. Nomor $07 \mathrm{Th}$ 2006 Tgl. 22 Agustus 2006. DOI: https://doi.org/10.36987/jes.v6i1.985

Key to Soil Taxonomy. 2016. Twelfth Edition 2014; Third edition of Indonesian Language. 2015. Indonesian Center for Agricultural Land Research and Development Agricultural Research and Development Agency. Ministry of Agriculture. United States Department of Agriculture. Natural Resources Conservation Service.

Kjeld Rasmussen. CheikhMbow. Yunjia Wang. Rasmus Fensholt. 2016. Remote sensing of vegetation dynamics in drylands: Evaluating vegetation optical depth (VOD) using AVHRR NDVI and in situ green biomass data over West African Sahel. Remote Sensing of Environment journal homepage: www.elsevier.com/locate/rse DOI: https://doi. org/10.1016/j.rse.2016.02.056

Map of Subang Regency Spatial and Regional Plan 2011-2031

Mohamed A.E. Abdel Rahman. A. Natarajan. Rajendra Hegde. 2016. Assessment of land suitability and capability by integrating remote sensing and GIS for agriculture in hamarajanagar district. Karnataka. India. National Authority for Remote Sensing and Space Sciences The Egyptian Journal of Remote Sensing and Space Sciences www.elsevier.com/locate/ejrs www.sciencedirect.com. DOI: https://doi.org/10.1016/j.ejrs.2016.02.001

Mufti Perwira Putra dan Muli Edwin. 2019. Analisis Status Kerusakan Tanah Pada Lahan Kering di Kampung Jawa Dusun Kabo Jaya. Sangatta. Jurnal Pertanian Terpadu 6 (2): 109-120 http:// ojs.stiperkutim.ac.id/index.php/jpt ISSN 2549-7383 (online) DOI: https://doi.org/10.36084/ jpt..v6i2.172

Nunung Sondari. 2017. Ilmu Kesuburan dan Kesehatan Tanah. LPPM Universitas Winaya Mukti ISBN : 978-979-16080-8-4. Karya Cipta yang telah terdaftar dalam Daftar Umum Ciptaan Direktorat Hak Cipta. Direktorat Jenderal Hak Kekayaan Intelektual. Kementerian Hukum Dan Hak Asasi Manusia R.I. Nomor Pencatatan : 000101054. DOI: https://doi.org/10.37631/ widyapranata.v1i2.47 
P. Schröder. B. Beckers. S. Daniels. F. Gnädinger. E.Maestri. N.Marmiroli. M.Mench. R. Millan. M.M. Obermeier. N. Oustriere. T. Perssonf. C. Poschenrieder. F. Rineau. B. Rutkowska. T. Schmid. W. Szulc. N.Witters. A. Sæbø. 2017. Intensify production. transform biomass to energy and novel goods and protect soils in Europe-A vision how to mobilize marginal lands. Science of the Total Environment journal homepage: www.elsevier.com/ locate/scitotenv. DOI: https://doi.org/10.1016/j.scitotenv.2017.10.209

Soil Research Institute. 2018. Analysis of Soil. Water. Plants and Fertilizers

Subang in Numbers. 2017. Subang Regency Statistics Agency. 